\title{
Geoderma
}

\section{Impact of fire and post-fire management techniques on soil chemical properties}

\author{
M.X. Gómez-Rey *, A. Couto-Vázquez, S. Garcia-Marco, SJ. González-Prieto
}

\begin{abstract}
A B S T R A C T
The effects of fire (Control burned soil) and two emergency stabilisation techniques (grass Seeding and straw Mulching) on 20 chemical characteristics were evaluated on $0-5 \mathrm{~cm}$ top-soils sampled $1,90,180$ and 365 days after an experimental fire in a steep shrubland of a temperate-humid region (NW Spain). Most part of $\mathrm{pH}$ (in $\mathrm{H}_{2} \mathrm{O}$ and $\mathrm{KCl}$ ) variance was explained by the sampling date. No clear temporal trends were identifiable for total soil $\mathrm{C}$ and $\mathrm{N}$ content, likely due to the large SOM pool in these soils; however, changes on soil $8^{13} \mathrm{C}$ were explained by the deposition of ${ }^{13} \mathrm{C}$-depleted ashes, followed by its progressive erosion, while those on soil $\mathrm{S}^{15} \mathrm{~N}$ were a consequence of fire induced $\mathrm{N}$ outputs. After the fire, $\mathrm{NH}^{\wedge}-\mathrm{N}, \mathrm{P}, \mathrm{Na}, \mathrm{K}, \mathrm{Mg}$, $\mathrm{Ca}, \mathrm{Mn}, \mathrm{Cu}, \mathrm{Zn}$ and $\mathrm{B}$ concentrations increased, while those of $\mathrm{NO}^{\wedge}-\mathrm{N}, \mathrm{Al}, \mathrm{Fe}$ and $\mathrm{Co}$ did not vary significantly. Despite a significant decline with time, concentrations of $\mathrm{Mg}, \mathrm{Ca}$ and $\mathrm{Mn}$ at the end of the study were still higher than in unburned soil, while those of $\mathrm{K}, \mathrm{Cu}, \mathrm{Zn}$ and $\mathrm{B}$ were similar to the pre-fire levels and those of Nftf-N, P and Na were below pre-fire values. Mulching and Seeding treatments for burned soil emergency stabilisation had significant effects on soil $8^{15} \mathrm{~N}$ and extractable $\mathrm{K}, \mathrm{Mg}$ and $\mathrm{Ca}$, while data were inconclusive for their possible effects on the extractable $\mathrm{Al}, \mathrm{Fe}$ and $\mathrm{Co}$.
\end{abstract}

\section{Introduction}

Although the use of fire by humans has modified forest ecosystems in NW Spain from at least 6000 years (Kaal et al., 2011), during the last decades this region became one of the areas with the highest fire incidence in Europe (Birot, 2009) due to a complex mixture of traditional use of fire as an agro-sylvo-pastoral tool, deep economic and demographic changes in rural areas and incendiarism as protest. Despite being a temperate-humid region, in Galicia from 1991 to 2010 more than 510,000 ha (almost one fifth of region's area) was burned by more than 175,000 wildfires (Ministerio de Agricultura y Medio Ambiente, 2012), causing huge economic and ecological damages that probably will be worse in the foreseeing scenario of climate change. Globally, forest fires are one of the most widespread factors of forest destruction (Chandler et al., 1983) and also a strong soil desertifying factor, because fire accelerate the processes of soil degradation and nutrient losses through volatilization, leaching and erosion (Certini, 2005).

Most studies on the effects of fire on soil chemical quality have been focussed on evaluating changes in organic matter and available macronutrients (e.g. Carballas, 1997; Couto-Váaquez and González-Prieto, 2006; Úbeda et al., 2006). Soil organic matter losses depend on fire severity, but are inexorable in burned areas (Simard et al., 2001). Nitrogen is the element most prone to direct losses to the atmosphere by combustion or $\mathrm{NH}_{3}$ volatilization (Fisher and Binkley, 2000) and ${ }^{15} \mathrm{~N}$ natural abundance has been employed to study the fire effects on $\mathrm{N}$ cycle in forests (Aranibar et al., 2003; Cook, 2001; Couto-Vázquez and González-Prieto, 2006). As the vegetation and litter pools of organic P are key on the cycle of this element, their simultaneous removal by fire exhausts aboveground $\mathrm{P}$ reserves at a rate higher than the supply by mineral weathering (DeBano et al., 1998), although fires mineralize organic-P to ortophosphate leading to a transient increase in $\mathrm{P}$ availability (Cade-Menun et al., 2000; Saa et al., 1994; Serrasolsas and Khanna, 1995). Fire increases the soil available cations (Debano and Conrad, 1978; Trabaud, 1983) due to the accumulation of ashes rich in oxides and carbonates of basic ions (Carballas, 1997; Certini, 2005; Chandler et al., 1983; Kutiel et al., 1990). Besides these effects on nutrient budgets of burned ecosystems, ashes also play a key role on soil hydrology and erosion (Bodi et al., 2011, 2012; Stoof et al., 2010; Woods and Balfour, 2008), and, then, on post-fire soil quality and conservation.

By the contrary, fewer studies have evaluated post-fire effects on soil micronutrients and results are sometimes contradictory. Soil available micronutrients often increased after fire, as extractable Mn and Zn (Close et al., 2011; Garcia-Marco and González-Prieto, 2008; Pivello et al., 2010), extractable Fe and B contents (Ponder et al., 2009) and extractable $\mathrm{Cu}$ (Brye et al., 2002; Stankov Jovanovic et al., 2011). However, lower levels of extractable Co (Garcia-Marco and González-Prieto, 2008), Fe and B (Close et al., 2011; Garcia-Marco and González-Prieto, 2008; Pivello et al., 2010) and $\mathrm{Cu}$ (Pivello et al., 2010) have also been reported, probably due to variations in fire intensity, precipitation regime and type of vegetation and soil. 
Although available micronutrients in soils are generally present in small quantities, post-fire changes could be especially important for plants and lead to deficiencies or to toxicity effects in some soils (Garcia-Marco and González-Prieto, 2008).

Wildfires can increase runoff and erosion by several orders of magnitude (e.g. Diaz-Fierros et al., 1987; Robichaud and Brown, 1999), mainly during the first months when the soil is bare, if intense rainfall events are frequent (Cerdà, 1998; Cerdà and Lasanta, 2005; Vega et al., 2005). Therefore, when the vegetation cover is completely destroyed by the fire, an emergency stabilisation treatment must be applied as soon as possible in the burned area to accelerate soil re-vegetation or to provide a ground cover with plant material, such as naturally occur with needles or leaves from not consumed canopy (Cerda and Doerr, 2008). Among these techniques, straw mulching and herbaceous seeding are commonly used (Fernandez et al., 2011; Groen and Woods, 2008; Robichaud, 2009; Vega et al., 2005). Although the effectiveness of emergency stabilisation techniques for reducing soil erosion has been studied (Diaz-Ravina et al., 2012; Fernandez et al., 2011; Groen and Woods, 2008; Wagenbrenner et al., 2006), their effects in burned soil quality has been scarcely quantified until recently (Diaz-Ravina et al., 2012; Fonturbel et al., 2012; Gomez-Rey et al., in press, submitted for publication).

Either if they are a natural component of many forest ecosystems (Turner et al., 2009) or modern creations of human habitation (Caldararo, 2002), wildfires affect most soil physical, chemical and biological properties (Certini, 2005) and, then, soil quality (Carballas, 1997). The working hypothesis of present study is that post-fire emergency stabilisation treatments can affect soil characteristics that determine soil quality. Thus, our aim was to evaluate during one year the effects of an experimental fire and two post-fire stabilisation techniques (seeding and mulching), on 20 soil chemical characteristics useful as soil quality indices.

\section{Material and methods}

\subsection{Site description and experimental design}

The experimental field was located in the Monte Cabalar $\left(42^{\circ} 38^{\prime}\right.$ $58^{\prime \prime} \mathrm{N} ; 8^{\circ} 29^{\prime} 31^{\prime \prime} \mathrm{W}, 660 \mathrm{~m}$ a.s.l.) at A Estrada (Galicia, NW Spain). The area has a temperate and rainy climate. During the study period (October 2009-December 2010), accumulated precipitation monitored in the area was $3036 \mathrm{~mm}$. The soil, developed over granite and with a slope of $38-54 \%$, has a sandy loam texture. Vegetation cover is dominated by Ulex europaeus L with some Pteridium aquilinum (L.) Kuhn., Ulex gallii Planch., Daboecia cantabrica (Huds.) K. Koch and Pseudoarrenhaterum longifolium Rouy, with an average height of $123 \mathrm{~cm}$ and $100 \%$ of ground cover.

After selecting an area of homogeneous slope, orientation, soil type and vegetation cover, 12 experimental plots (30x10 m each) were established with the longest dimension parallel to the maximum slope. On June 2009, the shrub was cut and laid down directly on the ground, to facilitate litter and duff combustion, and four months later (October 14th and 15th) plots were burned with the backfire technique to favour soil organic cover consumption and soil heating. The rate of fire spread was slow $\left(0.30-0.33 \mathrm{~m} \mathrm{~min}^{-1}\right)$ and the soil temperature reached, monitored with ten thermocouples $1<$ type per plot, was moderate at the mineral soil surface $\left(153{ }^{\circ} \mathrm{C}\right)$ and low at two centimetres soil depth $\left(34^{\circ} \mathrm{C}\right)$ (Fonturbel et al., 2012).

After the experimental fire, three soil treatments were arranged in a fully randomized design with four replications: a) burned soil, considered as Control treatment; b) Mulching, burned soil with $230 \mathrm{~g} \mathrm{~m} \sim^{2}$ of straw mulch; c) Seeding, burned soil with a mixture of seeds at a rate of $45 \mathrm{~g} \mathrm{~m} \sim^{2}$ (Lolium multiflorum, 35\%; Trifolium repens, 25\%; Dactylisglomerata, 20\%; Festuca arundinacea, 10\%; Festuca rubra, 5\%; Agrostis tenuis, 5\%). The soil stabilisation treatments were applied the 6th of November 2009 manually in order to minimize soil perturbation.

\subsection{Sampling and chemical analysis of soil}

Soil was sampled from the A horizon (0-5 $\mathrm{cm}$ depth, including the ash layer) immediately before the experimental fire and after 1, 90, 180 and 365 days. In each occasion, ten squares $(15 \times 15 \mathrm{~cm})$, uniformly distributed inside each plot, were taken and combined to obtain a composite sample. The field-moist soil was sieved $(<2 \mathrm{~mm})$, homogenised and stored at $4{ }^{\circ} \mathrm{C}$ for inorganic $\mathrm{N}$ determination. Sub-samples were air-dried for chemical analyses.

The $\mathrm{pH}$ was measured with a $\mathrm{pH}$-meter (Metrbhm, Switzerland) in $\mathrm{H}_{2} \mathrm{O}$ and $\mathrm{KCl}$ employing a soihsolution ratio of 1:2.5. Total C, total $\mathrm{N}, \quad 6^{13} \mathrm{C}$ and $6^{15} \mathrm{~N}$ were measured on finely ground soil samples (<100um) with an elemental analyser (Carlo Erba CNS 1508) coupled on-line with an isotopic ratio mass spectrometer (Finnigan Mat, delta $\mathrm{C}$, Bremen, Germany). Inorganic $\mathrm{N}$ was extracted by shaking $20 \mathrm{~g}$ of soil for $1 \mathrm{~h}$ with $2 \mathrm{M} \mathrm{KCl} \mathrm{(1:5} \mathrm{soihsolution} \mathrm{ratio).} \mathrm{Extracts}$ were passed through glass microfibre filters (Whatman GF/A, 125 diameter) and NOJ-N and $\mathrm{NH}^{\wedge}-\mathrm{N}$ were analysed by a modified diffusion method (Khan et al., 1997). In order to sequentially liberate $\mathrm{NH}^{\wedge}-\mathrm{N}$ and $\mathrm{NO}^{\wedge}+\mathrm{NO}_{3} \sim-\mathrm{N}$ in the form of $\mathrm{NH}_{3}, 50 \mathrm{ml}$ aliquots of extracts, placed in a $500 \mathrm{ml}$ wide-mouth glass jar, were treated successively $\left(24 \mathrm{~h}\right.$ periods at $\left.50{ }^{\circ} \mathrm{C}\right)$ with $\mathrm{MgO}(0.1 \mathrm{~g})$ and $\mathrm{MgO}(0.1 \mathrm{~g})$ plus Devarda's alloy $(0.4 \mathrm{~g})$. Gaseous $\mathrm{NH}_{3}$ was trapped into $10 \mathrm{ml}$ of $0.004 \mathrm{M} \mathrm{H}_{2} \mathrm{SO}_{4}$ in a Teflon bottle attached to the glass jar and measured by back titration of the excess of $\mathrm{H}_{2} \mathrm{SO}_{4}$ with $0.004 \mathrm{M} \mathrm{NaOH}$. For extractable $\mathrm{Na}, \mathrm{K}, \mathrm{Mg}, \mathrm{Ca}, \mathrm{P}, \mathrm{Al}, \mathrm{B}, \mathrm{Co}, \mathrm{Cu}, \mathrm{Fe}, \mathrm{Mn}$ and $\mathrm{Zn}$ analyses, soils $(10 \mathrm{~g})$ were shaken for $2 \mathrm{~h}$ with a mixture of $1 \mathrm{M} \mathrm{NH}_{4} \mathrm{Ac}$ and $0.005 \mathrm{M}$ DTPA as extracting solution (1:5 soihsolution ratio); the extracts were filtered through cellulose paper (Filter-laboratory 1242, 90-mm diameter) and then analysed by simultaneous 1CP-OES (Varian Vista Pro, Mulgrave, Australia). All analyses were carried out in duplicate and the mean of both analyses was used in the statistical procedure.

\subsection{Statistical analysis}

Data on soil chemical characteristics were statistically analysed by two-way ANOVA, with treatment and sampling date as factors. The Levene's test was used for verifying the equality of variances among groups. In the case of homocedasticity, significant differences among the mean groups were established at $\mathrm{p}<0.05$ using the Bonferroni's test for multiple comparisons. In the case of unequal variances, the original data were subjected to Cox-Box transformations to obtain equality of variances and then significant differences among the mean groups were established at $\mathrm{p}<0.05$ using the Bonferroni's test.

Simple regression models between soil properties as dependent variables and time after fire (in days or its logarithmic transformation) as independent variable were done after checking the fulfilment of the assumptions of linear regressions (independence, homocedasticity and normality). Statistical procedures were performed with SPSS 15.0 for Windows.

\section{Results}

Before the experimental fire there were no significant differences among the plots assigned to the different treatments for any of the variables studied showing an acceptable spatial homogeneity of the study area.

The two-way ANOVA for soil $\mathrm{pH}$, in $\mathrm{H}_{2} \mathrm{O}$ and $\mathrm{KCl}$, showed that $88 \%$ and $42 \%$, respectively, of their variation was explained by the sampling date, while the emergency stabilisation treatments had no significant effect (Table 1, Fig. 1). The evolution of soil $\mathrm{pH}$ during the study period fitted to a linear regression model with days after fire 
Table 1

Results of the two-way ANOVA for the main soil characteristics $\left(\mathrm{pH}, 8^{13} \mathrm{C}, 8^{15} \mathrm{~N}\right.$ and nutrient concentrations) with treatment and date as factors. No significant treatmentxdata interaction was observed for any variable.

\begin{tabular}{|c|c|c|}
\hline & Treatment & Date \\
\hline & Partial $r^{2} \mathrm{p}$ & Partial rf $p$ \\
\hline $\mathrm{pHH}_{2} \mathrm{O}$ & 0.020 n.s. & $0.877 * * *$ \\
\hline $\mathrm{pH} \mathrm{KCl}$ & 0.118 n.s. & 0.418 **** \\
\hline Total C $\left(\mathrm{gleg}_{-}{ }^{1}\right)$ & 0.028 n.s. & 0.173 n.s. \\
\hline $8^{13} \mathrm{C}(\mathrm{S} \& \mathrm{O}$ & 0.095 n.s. & $0.250 * *$ \\
\hline Total $\mathrm{N}\left(\mathrm{g} \mathrm{kg}^{1}\right)$ & 0.001 n.s. & $0.245^{*}$ \\
\hline $8^{15} \mathrm{~N}(\% \mathrm{o})$ & $0.132 *$ & $0.754 * * *$ \\
\hline $\left.\mathrm{NHj}-\mathrm{Nfmgkg}{ }_{-}{ }^{1}\right)$ & 0.033 n.s. & $0.913^{* * *}$ \\
\hline NOJ-Nfmgkg"1) & 0.094 n.s. & $0.719 * * *$ \\
\hline Extractable $\mathrm{Al}\left(\mathrm{mg} \mathrm{kg}^{-1}\right)$ & $0.126^{*}$ & 0.192 n.s. \\
\hline Extractable $\mathrm{Na}\left(\mathrm{mg} \mathrm{kg}^{-1}\right)$ & 0.059 n.s. & $0.960 * * *$ \\
\hline Extractable $\mathrm{K}\left(\mathrm{mg} \mathrm{kg}^{-1}\right)$ & $0.217^{* *}$ & $0.857 * * *$ \\
\hline Extractable $\mathrm{Mg}\left(\mathrm{mg} \mathrm{kg}^{-1}\right)$ & $0.176^{*}$ & $0.856^{* * * *}$ \\
\hline Extractable $\mathrm{Ca}\left(\mathrm{mg} \mathrm{kg}^{-1}\right)$ & $0.159^{*}$ & $0.782 * * * *$ \\
\hline Extractable $\mathrm{P}\left(\mathrm{mg} \mathrm{kg}^{-1}\right)$ & 0.008 n.s. & $0.813^{* * *} *$ \\
\hline Extractable $\mathrm{Fe}\left(\mathrm{mg} \mathrm{kg}^{-1}\right)$ & $0.147^{*}$ & $0.315^{* *}$ \\
\hline Extractable $\mathrm{Mn}\left(\mathrm{mg} \mathrm{kg}^{-1}\right)$ & 0.044 n.s. & $0.735^{* * *}$ \\
\hline Extractable $\mathrm{Cu}\left(\mathrm{mg} \mathrm{kg}^{-1}\right)$ & 0.001 n.s. & $0.896^{* * * *}$ \\
\hline Extractable $\mathrm{Zn}\left(\mathrm{mg} \mathrm{kg}^{-1}\right)$ & 0.012 n.s. & $0.582 * * *$ \\
\hline Extractable $\mathrm{B}\left(\mathrm{mg} \mathrm{kg}^{-1}\right)$ & 0.015 n.s. & $0.917 * * *$ \\
\hline Extractable Co $\left(\mathrm{mg} \mathrm{kg}^{-1}\right)$ & $0.139 *$ & $0.303 * *$ \\
\hline
\end{tabular}

n.s. not significant

$* * * * \mathrm{p}<0.001$.

$* * \mathrm{p}<0.01$.

$* \mathrm{p}<0.05$.

as independent variable, explaining the $71 \%$ and $36 \%\left(\mathrm{pH}\right.$ in $\mathrm{H}_{2} \mathrm{O}$ and $\mathrm{KCl}$, respectively) of the variance (Table 2).

Soil $\mathrm{N}$ concentration (Fig. 2a) was not affected by the soil stabilisation treatments, but the two-way ANOVA showed a slight effect $(\mathrm{p}<0.05 ; 24 \%$ ofvariance explained; Table 1$)$ of sampling date, although no temporal trend could be identified. The soil $6{ }^{15} \mathrm{~N}$ (Fig. $2 \mathrm{~b}$ ) was slightly affected by the emergency stabilisation treatments ( $\mathrm{p}<0.05 ; 13 \%$ of variance explained; Table 1$)$, increasing in the order Mulching (2.89\%»), Seeding (3.00\%») and Control (3.28\%»), differences being only significant between the first and the last. Sampling date had a strong effect on soil $6^{15} \mathrm{~N}(\mathrm{p}<0.001 ; 75 \%$ of variance explained; Table 1), with lowest values at $\mathrm{t}=0,1$ and $90 \mathrm{~d}$ (2.31 to $2.65 \% \mathrm{o})$, intermediate at $\mathrm{t}=180 \mathrm{~d}(3.39 \% »)$, and highest at $\mathrm{t}=365 \mathrm{~d}$ (4.38\%o; Fig. 2b). A simple linear regression model of soil $6{ }^{15} \mathrm{~N}$ with days after fire as independent variable explained $73 \%$ of its variance $(\mathrm{p}<0.0005$; Table 2).

The two-way ANOVA showed no effect of soil stabilisation treatments on NH/-N, which was strongly influenced $(\mathrm{p}<0.001 ; 91 \%$ of variance explained; Table 1) by sampling date, with a high, but transient, increase just after the fire $\left(119 \mathrm{mg} \mathrm{kg}^{-1}\right)$, a steady decline

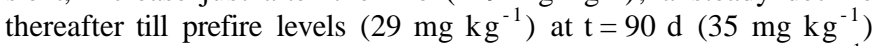
and significantly lower at $\mathrm{t}=180$ and $365 \mathrm{~d}\left(10-12 \mathrm{mg} \mathrm{kg}^{-1}\right.$; Fig 2c). Like $\mathrm{NH}^{\wedge}-\mathrm{N}$, soil $\mathrm{NO}^{\wedge}-\mathrm{N}$ concentration was not affected by the emergency stabilisation treatments and it was strongly influenced ( $p<0.001 ; 72 \%$ ofvariance explained; Table 1$)$ by sampling date, with the highest values just before and after the fire (64 and $51 \mathrm{mg} \mathrm{kg} 1$ respectively), intermediate at $\mathrm{t}=90 \mathrm{~d}\left(37 \mathrm{mg} \mathrm{kg}^{-1}\right)$ and lowest at $\mathrm{t}=180$ and $365 \mathrm{~d}$ (20 and $15 \mathrm{mg} \mathrm{kg}^{11}$, respectively). Both NH/-N and NOJ-N concentrations in soils can be fitted to simple linear regression models with the logarithm of days after fire as independent variable that explained $91 \%$ and $39 \%$, respectively, of their variances $\left(p<0.0005\right.$; Table 2). However, for the $\mathrm{NO}_{3} \sim-\mathrm{N}$ concentration the fitting was only slightly better than that with days after fire (31\% of variance explained; $\mathrm{p}<0.0005$, data not shown).

Neither the soil stabilisation treatments nor the sampling date affected the $\mathrm{C}$ content (Fig. 2e), as shown by the two-way ANOVA (Table 1); however, the ${ }^{13} \mathrm{C}$ natural abundance was influenced by sampling date $(p<0.01 ; 25 \%$ ofvariance explained $)$, with similar values

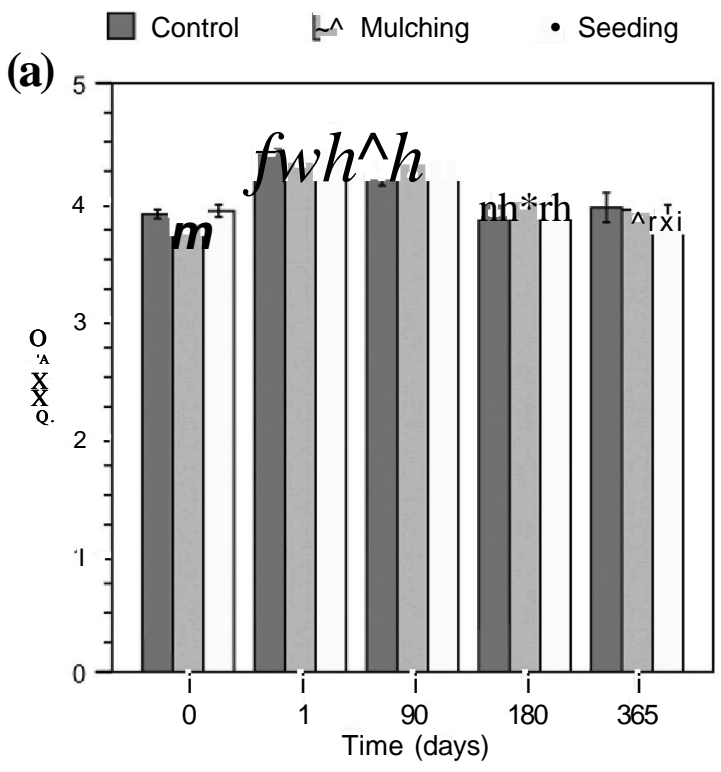

(b)

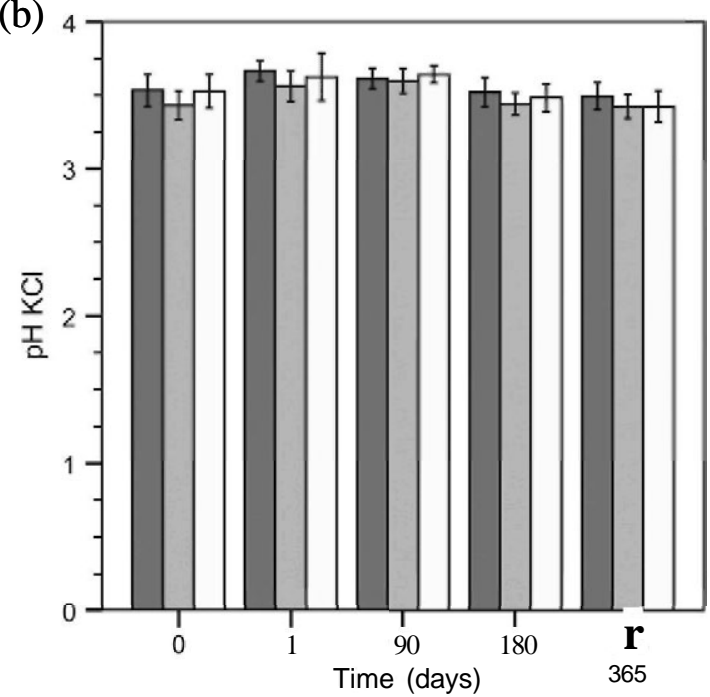

Fig. 1. Evolution of $\mathrm{pH}$ in $\mathrm{H}_{2} \mathrm{O}$ (a) and $\mathrm{KC}$ (b) in the $0-5 \mathrm{~cm}$ soil layer along a year after the experimental Are in the Control, Seeding and Mulching treatments. For each sampling date, no significant differences between treatments were found.

before the fire and at $\mathrm{t}=365 \mathrm{~d}(-27.03 \pm 0.17 \% \mathrm{o})$ and more negative at the other dates $(-27.17 \pm 0.16 \%$; Fig. 2f), although differences were only significant between soils collected at $\mathrm{t}=90$ and $365 \mathrm{~d}$.

Table 2

Best linear regression models $(\mathrm{p}<0.0005)$ between main soil characteristics and time after Are (days) as independent variable.

\begin{tabular}{llc}
\hline & $\mathrm{R}^{2}$ & Equation \\
\hline $\mathrm{pHH}{ }_{2} \mathrm{O}$ & 0.711 & $\mathrm{y}=4.40-(0.0015-\mathrm{x})$ \\
$\mathrm{pH} \mathrm{KC}$ & 0.360 & $\mathrm{y}=3.63-(0.00052-\mathrm{x})$ \\
$8^{.5} \mathrm{~N}$ & 0.726 & $\mathrm{y}=2.27+(0.0056-\mathrm{x})$ \\
$\mathrm{NH}^{\wedge}-\mathrm{N}$ & 0.911 & $\mathrm{y}=119-(44.3-\log \mathrm{x})$ \\
$\mathrm{NOJ}-\mathrm{N}$ & 0.389 & $\mathrm{y}=52.2-(12.7-\log \mathrm{x})$ \\
Extractable $\mathrm{Na}$ & 0.925 & $\mathrm{y}=219-(74.4-\log \mathrm{x})$ \\
Extractable $\mathrm{K}$ & 0.827 & $\mathrm{y}=543-(168-\log \mathrm{x})$ \\
Extractable $\mathrm{Mg}$ & 0.697 & $\mathrm{y}=208-(52.9-\log \mathrm{x})$ \\
Extractable Ca & 0.709 & $\mathrm{y}=288-(78.9-\log \mathrm{x})$ \\
Extractable $\mathrm{P}$ & 0.682 & $\mathrm{y}=25.6-(6.21-\log \mathrm{x})$ \\
Extractable $\mathrm{Mn}$ & 0.752 & $\mathrm{y}=22.86-(7.24-\log \mathrm{x})$ \\
Extractable $\mathrm{Cu}$ & 0.755 & $\mathrm{y}=3.48-(0.349-\log \mathrm{x})$ \\
Extractable $\mathrm{Zn}$ & 0.493 & $\mathrm{y}=0.377-(0.137-\log \mathrm{x})$ \\
Extractable $\mathrm{B}$ & 0.783 &
\end{tabular}


(a)

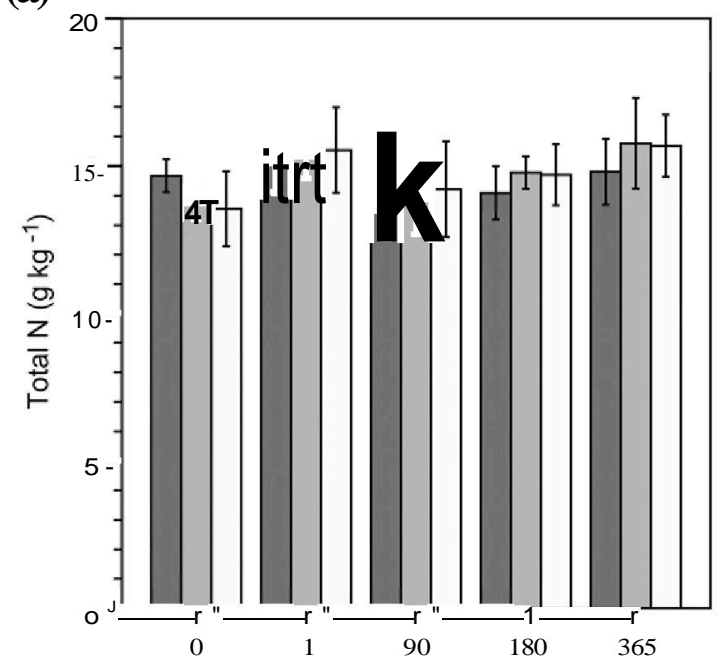

(c)

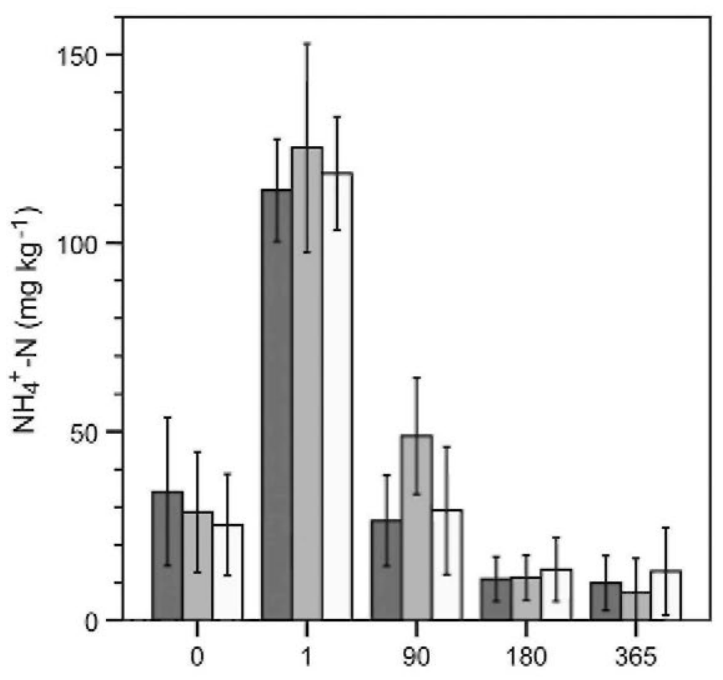

(e)

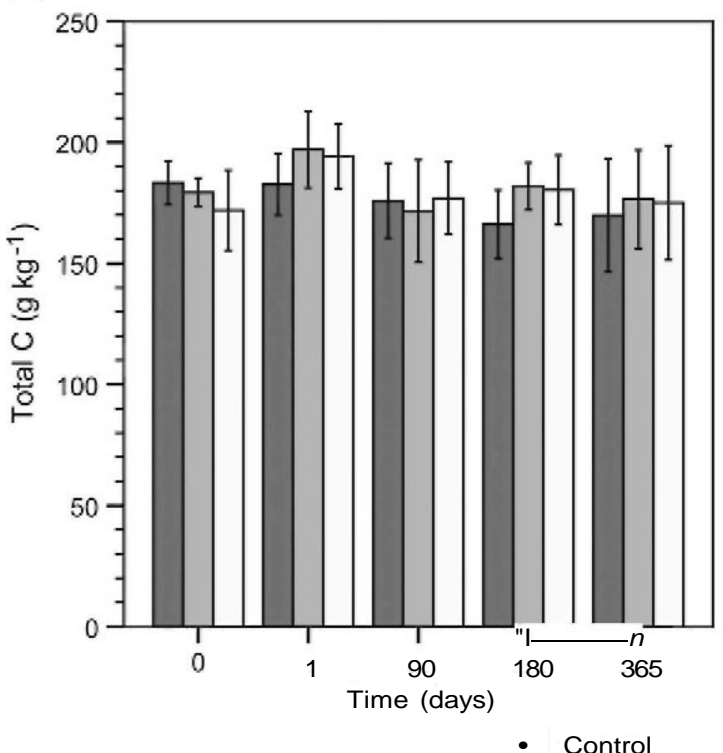

(b)

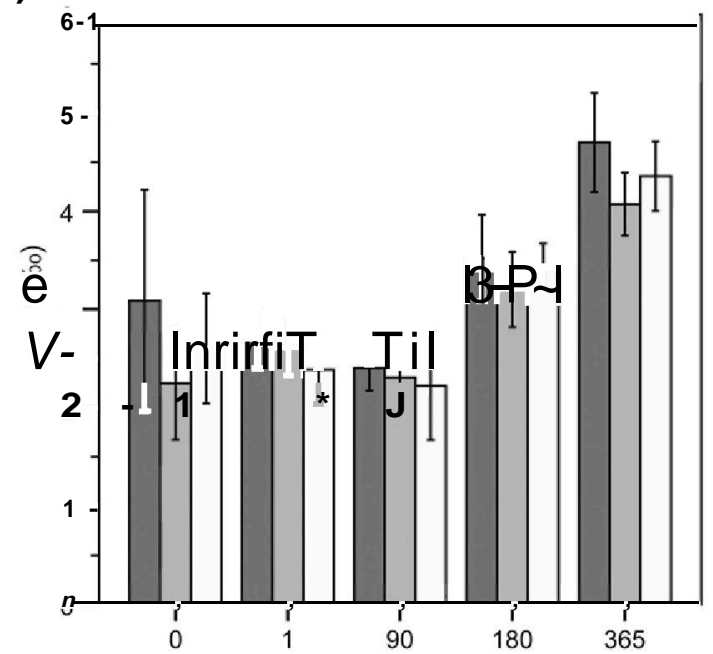

(d)

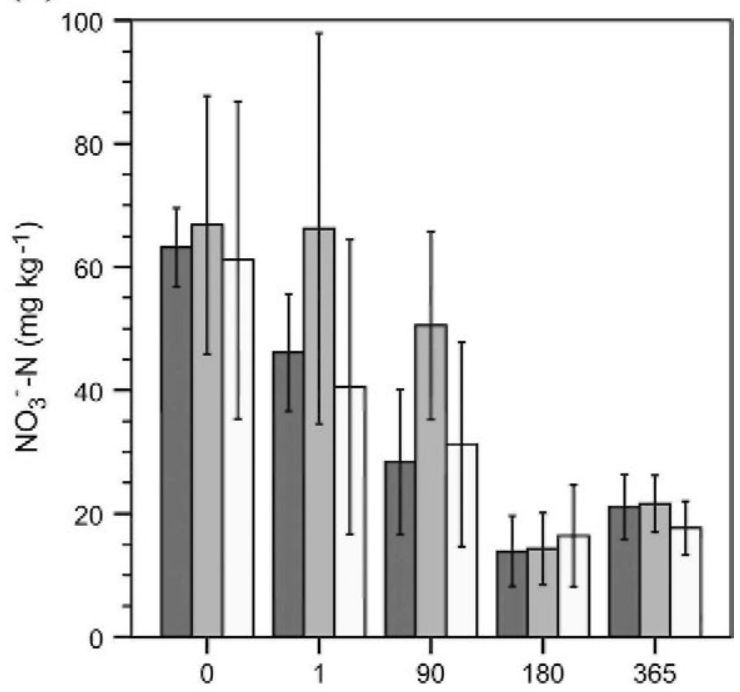

(f)

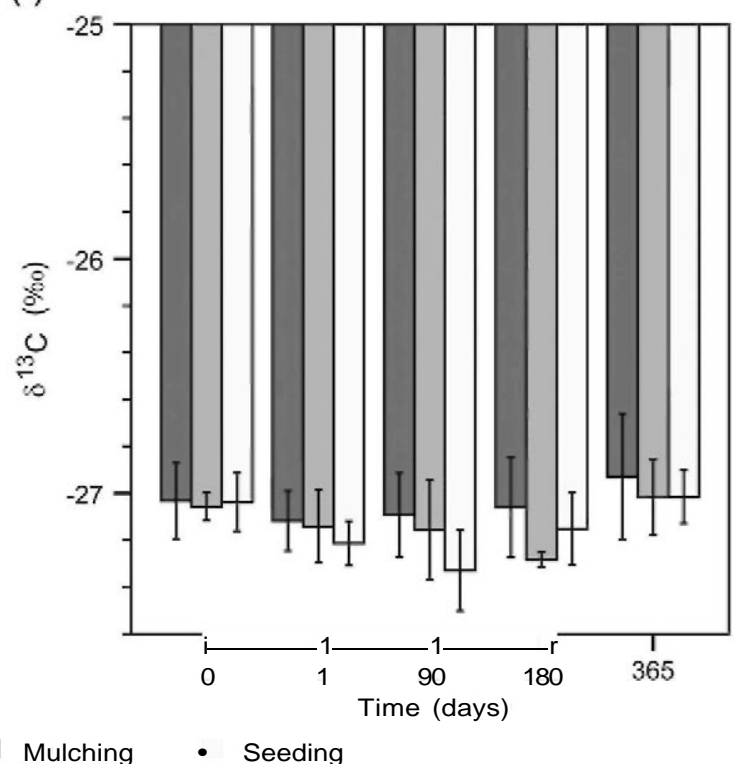

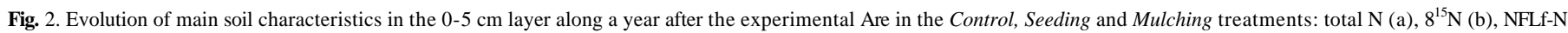
(c), NO ${ }^{\wedge}-\mathrm{N}(\mathrm{d})$, total $\mathrm{C}$ (e) and $8^{13} \mathrm{C}$ (f). For each sampling date, no significant differences between treatments were found. 
(a)

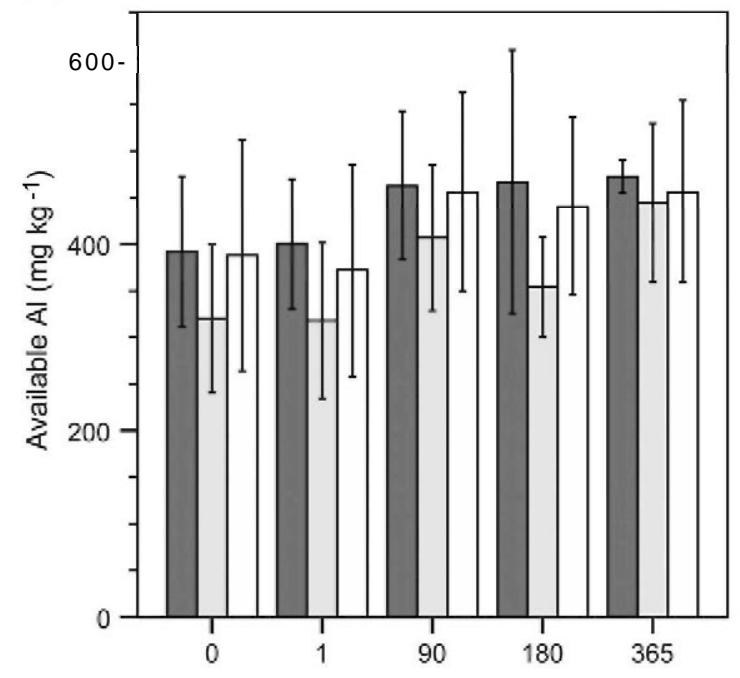

(c)

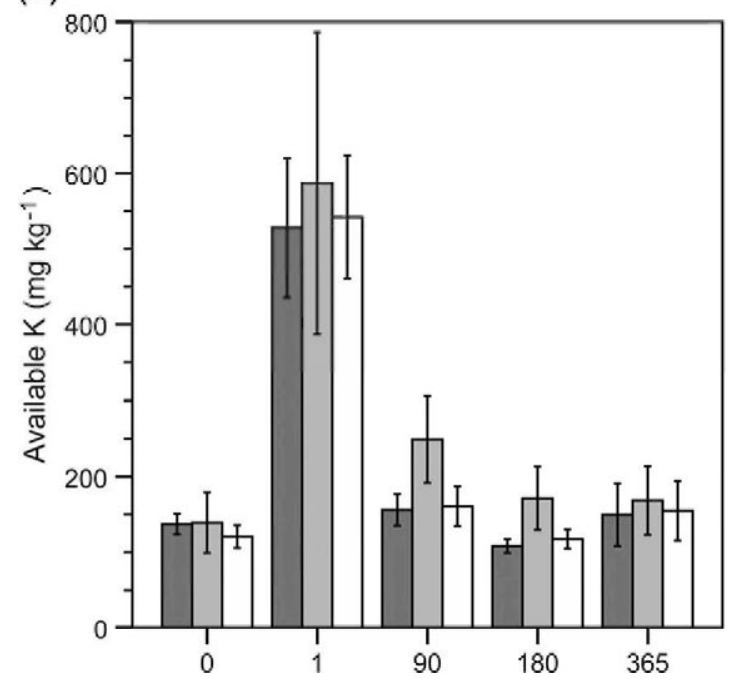

(e)

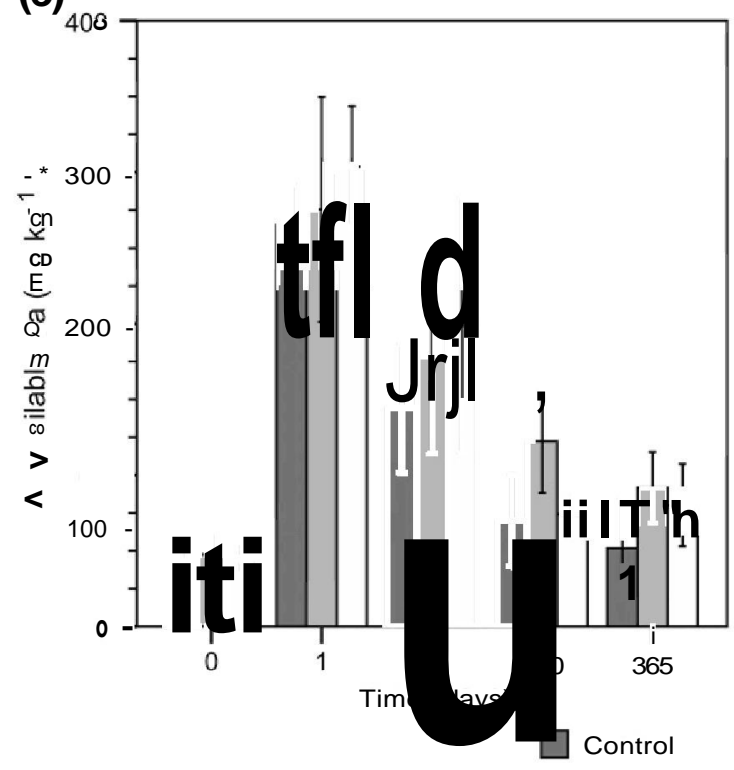

(b)

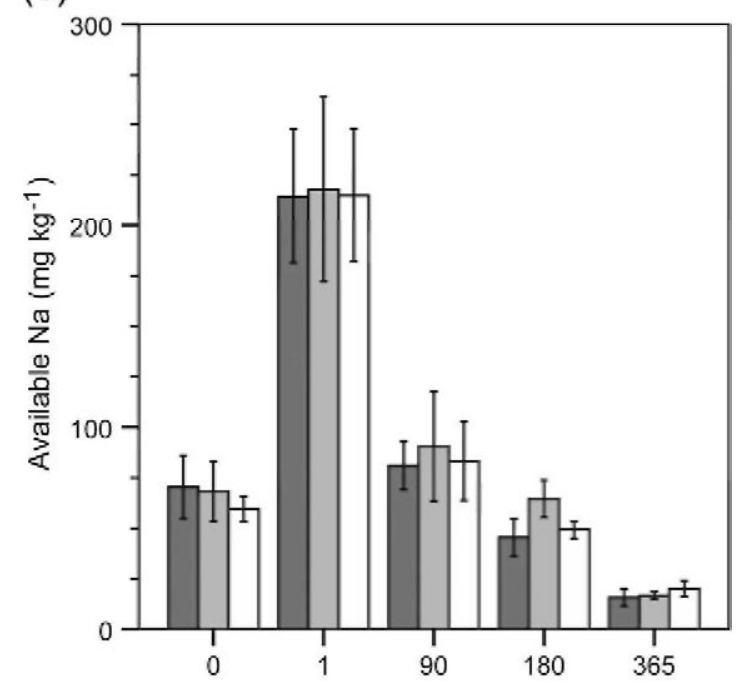

(d)

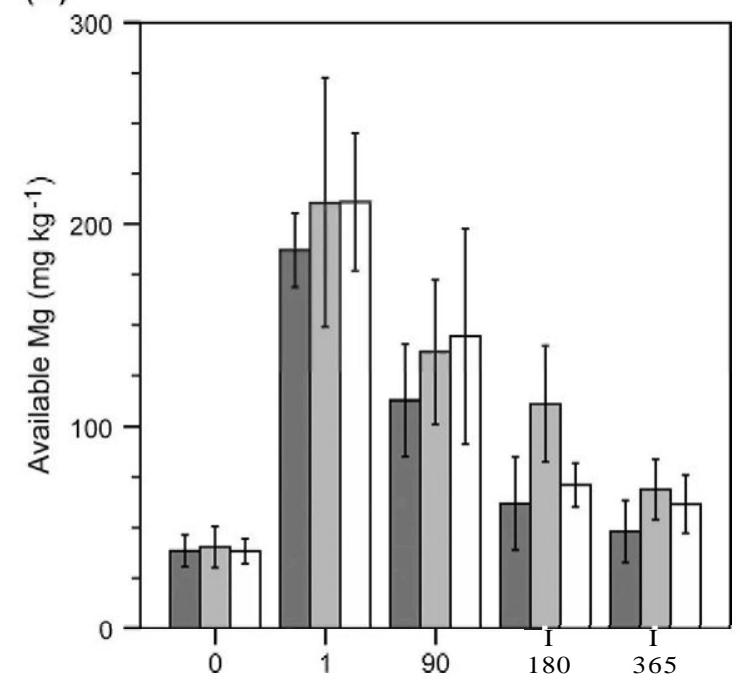

(f)

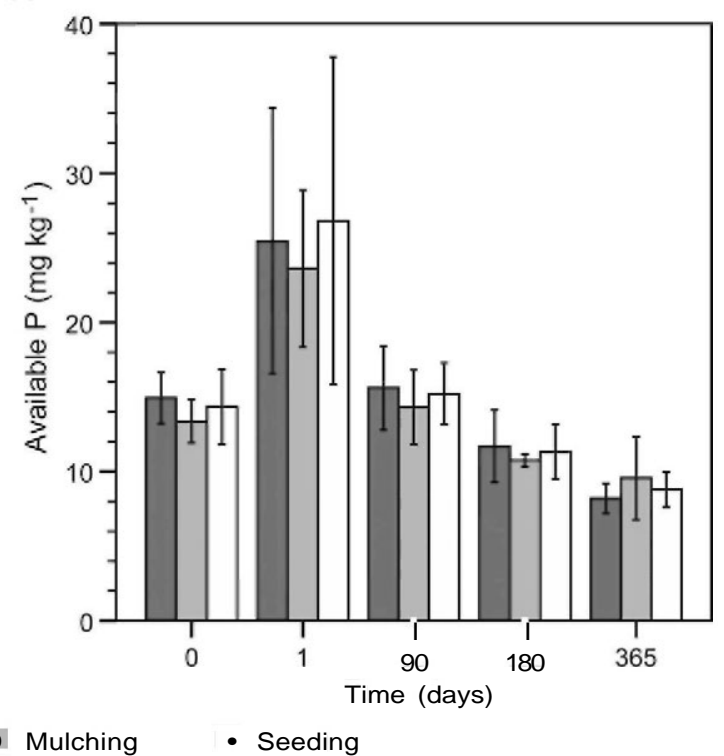

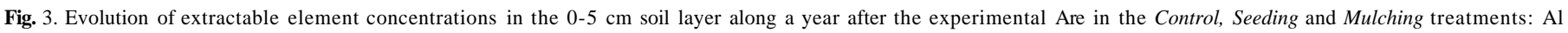
(a), Na (b), K (c), Mg (d), Ca (e) and P (f). For each sampling date, no significant differences between treatments were found. 
Sampling date had no effect on soil extractable Al (Fig. 3a), which varied slightly but significantly among emergency stabilisation treatments ( $<<0.05 ; 13 \%$ ofvariance explained; Table 1$)$, with the highest values in Control (4.39 $\mathrm{mg} \mathrm{kg}^{-1}$; Fig. 3a), lowest in Mulching (3.69 $\mathrm{mg} \mathrm{kg}^{-1}$ ) and intermediate in Seeding (4.23 $\mathrm{mg} \mathrm{kg}^{-1}$ ).

Treatment and sampling date had significant effects on available basic cation concentrations (Fig. 3b, c, d and e), explaining 16-22\% and $78-86 \%$ of their variances, respectively (Table 1). Concentrations were significantly higher in Mulching (263,114 and $143 \mathrm{mg} \mathrm{kg}^{-1}$ for $\mathrm{K}, \mathrm{Mg}$ and Ca, respectively) than in Control (216,90 and $115 \mathrm{mg} \mathrm{kg}^{-1}$ for $\mathrm{K}, \mathrm{Mg}$ and $\mathrm{Ca}$, respectively), intermediate values being found in Seeding (219, 105 and $140 \mathrm{mg} \mathrm{kg}^{-1}$ for $\mathrm{K}, \mathrm{Mg}$ and $\mathrm{Ca}$, respectively); no differences among treatments were detected for $\mathrm{Na}$. The concentrations of available basic cations in burned soils, with or without stabilisation techniques, were higher than in the unburned soils up until $\mathrm{t}=90 \mathrm{~d}\left(\mathrm{Na}, 85-216 \mathrm{mg} \mathrm{kg}^{-1} ; \mathrm{K}, 189-552 \mathrm{mg} \mathrm{kg}^{-1} ; \mathrm{Mg}\right.$, 131-203 mg kg-1; Ca, 174-281 $\mathrm{mg} \mathrm{kg}^{-1}$; Fig. 3). Despite a significant decline with time, concentrations of divalent cations at the end of the study (60 and $75 \mathrm{mg} \mathrm{kg}^{-1}$ of $\mathrm{Mg}$ and $\mathrm{Ca}$, respectively) were still higher than in unburned soil (39 and $45 \mathrm{mg} \mathrm{kg}^{-1}$ of $\mathrm{Mg}$ and $\mathrm{Ca}$, respectively). In contrast, concentrations of monovalent cations showed a fast reduction, returning to pre-fire levels at $\mathrm{t}=180 \mathrm{~d}$ (Na, $53 \mathrm{mg} \mathrm{kg}^{-1} ; \mathrm{K}, 133 \mathrm{mg} \mathrm{kg}^{-1}$ ); Na concentration decreased to even below pre-fire values at $\mathrm{t}=365 \mathrm{~d}\left(18 \mathrm{mg} \mathrm{kg}^{-1}\right)$.

According to the two-way ANOVA, soil extractable $\mathrm{P}$ was only affected by the sampling date $(\mathrm{p}<0.001 ; 81 \%$ of variance explained; Table 1). Phosphorous concentration rose just after fire till $25 \mathrm{mg} \mathrm{kg}^{-1}$ (Fig. 3f), but at $\mathrm{t}=90 \mathrm{~d}$ it returned to prefire levels (14-15 $\left.\mathrm{mg} \mathrm{kg}^{-1}\right)$ and it continued to decrease at $\mathrm{t}=180 \mathrm{~d}$ $\left(11 \mathrm{mg} \mathrm{kg}^{-1}\right)$ and $\mathrm{t}=365 \mathrm{~d}\left(9 \mathrm{mg} \mathrm{kg}^{-1}\right)$, all differences being significant $(\mathrm{p}<0.05$ to $\mathrm{p}<0.001)$. A simple linear regression model with the logarithm of days after fire as independent variable explained $68 \%$ of extractable $P$ variance $(\mathrm{p}<0.0005$; Table 2$)$.

The concentration of all basic cations along the study period can be fitted to simple linear regression models with the logarithm of days after fire as independent variable that explained 93\%, 83\%, 70\% and $71 \%$ of $\mathrm{Na}, \mathrm{K}, \mathrm{Mg}$ and $\mathrm{Ca}$ variances, respectively, $(\mathrm{p}<0.0005$; Table 2). However, for the divalent cations the fitting was only slightly better than that with days after fire $(63 \%$ and $60 \%$ of variance explained, respectively; $\mathrm{p}<0.0005$, data not shown).

Available $\mathrm{Fe}$ concentration varied significantly among treatment and sampling date groups (15\% and $31 \%$ of variance explained, respectively); the highest values were found in Mulching (579 $\mathrm{mg} \mathrm{kg}^{-1}$ ), the lowest in Control (438 $\mathrm{mg} \mathrm{kg}^{-1}$ ) and intermediate in Seeding (497 $\mathrm{mg} \mathrm{kg}^{-1}$ ). While the available Fe concentrations varied without a clear tendency during the first 180 days of the study (453-614 $\mathrm{mg} \mathrm{kg}^{-1}$; Fig. 4a), a significant reduction was observed at $\mathrm{t}=365 \mathrm{~d}\left(363 \mathrm{mg} \mathrm{kg}^{-1}\right)$ when compared to those obtained at $\mathrm{t}=90$ and at $\mathrm{t}=180 \mathrm{~d}$ (614 and $568 \mathrm{mg} \mathrm{kg}^{-1}$, respectively).

The two-way ANOVA showed that the emergency stabilisation treatments had no significant effect on available $\mathrm{Mn}, \mathrm{Cu}, \mathrm{Zn}$ and $\mathrm{B}$ concentrations, however they were strongly influenced by the sampling date (58-92\% ofvariance explained). In all cases, concentrations increased significantly just after the experimental fire $(22.8,0.92,3.39$ and $0.40 \mathrm{mg} \mathrm{kg}^{-1}$ for $\mathrm{Mn}, \mathrm{Cu}, \mathrm{Zn}$ and $\mathrm{B}$, respectively at $\mathrm{t}=1 \mathrm{~d}$ ) when compared with unburned soils $\left(3.0,0.10,1.64\right.$ and $0.14 \mathrm{mg} \mathrm{kg}^{-1}$ for $\mathrm{Mn}, \mathrm{Cu}, \mathrm{Zn}$ and $\mathrm{B}$, respectively), but the subsequent evolution of each element differed (Fig. 4b, c, d and e). Three months later, a significant reduction of available $\mathrm{Mn}$ concentrations was observed $\left(9.6 \mathrm{mg} \mathrm{kg}^{-1}\right)$, values remaining stable $\left(4.9-5.2 \mathrm{mg} \mathrm{kg}^{-1}\right)$, but higher than in the unburned soil $\left(3.0 \mathrm{mg} \mathrm{kg}^{-1}\right)$, up until the end of the study period. By the contrary, a fast decline was observed for available $\mathrm{Cu}$ concentrations and values returned to prefire levels since $\mathrm{t}=90 \mathrm{~d}\left(0.05-0.14 \mathrm{mg} \mathrm{kg}^{-1}\right)$. The increase in $\mathrm{Zn}$ concentrations was still evident 90 days after the fire $\left(2.56 \mathrm{mg} \mathrm{kg}^{-1}\right)$, but concentrations significantly decreased at $\mathrm{t}=180$ and $\mathrm{t}=365 \mathrm{~d}$ until values $\left(1.39-1.53 \mathrm{mg} \mathrm{kg}^{-1}\right)$ similar to those of the unburned soils $\left(1.64 \mathrm{mg} \mathrm{kg}^{-1}\right)$. After the initial increase, available B concentrations fell significantly, values being similar $\left(0.11 \mathrm{mg} \mathrm{kg}^{-1} ; \mathrm{t}=365 \mathrm{~d}\right)$ or even lower $\left(0.02-0.06 \mathrm{mg} \mathrm{kg}^{-1}\right.$ at $\mathrm{t}=90$ and $\left.\mathrm{t}=180 \mathrm{~d}\right)$ than those found in unburned soils $\left(0.14 \mathrm{mg} \mathrm{kg}^{-1}\right)$. Despite these differences, the concentration of these trace element along the study can be fitted to simple linear regression models with the logarithm of days after fire as independent variable that explained $75 \%, 76 \%, 49 \%$ and $78 \%$, respectively, of $\mathrm{Mn}, \mathrm{Cu}, \mathrm{Zn}$ and $\mathrm{B}$ variances ( $\mathrm{p}<0.0005$; Table 2), although for $\mathrm{Zn}$ the fitting was only marginally better than that with days after fire $(47 \%$ of variance explained; $p<0.0005$, data not shown).

Available Co concentrations (Fig. 4f) varied significantly among treatment and sampling date groups (14\% and $30 \%$ ofvariance explained; Table 1), with the highest values in Mulching $\left(0.084 \mathrm{mg} \mathrm{kg}^{-1}\right)$, the lowest in Control $\left(0.067 \mathrm{mg} \mathrm{kg}^{-1}\right)$ and intermediate in Seeding plots $\left(0.074 \mathrm{mg} \mathrm{kg}^{-1}\right)$. The available Co contents varied without a clear trend during the study period, significant differences being only observed between $\mathrm{t}=90$ and $\mathrm{t}=365 \mathrm{~d}\left(0.091\right.$ and $0.057 \mathrm{mg} \mathrm{kg}^{-1}$, respectively).

\section{Discussion}

Considering that for soil $\mathrm{pH}$ in $\mathrm{H}_{2} \mathrm{O}$ most part of the variance was explained by the sampling date, it can be concluded that the oxides and carbonates of basic ions supplied by ashes (Certini, 2005) were steadily lost by leaching and runoff (Lasanta and Cerdà, 2005), as well as with the eroded sediments (Gómez-Rey et al., in press). As a measure of potential acidity, $\mathrm{pH}$ in $\mathrm{KCl}$ showed few changes during the study period, but almost half of its variance was still explained by the sampling date. Neither for $\mathrm{pH}$ in $\mathrm{H}_{2} \mathrm{O}$ nor in $\mathrm{KCl}$ the emergency stabilisation treatments had a noticeable effect.

Despite the erosion of N-rich sediments throughout the whole study (see Gómez-Rey et al., in press), a clear temporal trend could not be identified for the soil $\mathrm{N}$ content, likely due to the big $\mathrm{N}$ pool in these soils. However, the strong positive linear relationship of soil $6{ }^{15} \mathrm{~N}$ with the time after fire clearly suggests that the experimental fire promoted $\mathrm{N}$ outputs, as also found Couto-Vázquez and González-Prieto (2006) and Saito et al. (2007). This result was undoubtedly a result of an increase in the lixiviation of nitrates (Lasanta and Cerda, 2005), which are ${ }^{15} \mathrm{~N}$ depleted (Hbgberg et al., 1995), and to the erosion of ${ }^{15} \mathrm{~N}$ depleted sediments (Gomez-Rey et al., in press). As N losses by erosion were reduced slightly by Seeding and strongly by Mulching (Gomez-Rey et al., in press), and probably the same was true for nitrate leaching, the consequence is that the emergency stabilisation treatments mitigated the post-fire $6{ }^{15} \mathrm{~N}$ increase.

The transient increase found for the NH/-N just after the experimental fire, a common fact in burned soils (Certini, 2005; Chandler et al., 1983; Couto-Vázquez and González-Prieto, 2006; Debano and Conrad, 1978; Prieto-Fernandez et al., 1993), was likely a consequence of decomposition of soil organic $\mathrm{N}$ and the liberation of soil mineral $\mathrm{N}$ due to heating (Russell et al., 1974). Nevertheless, the decline of NH/-N concentrations in present study (linear with the logarithm of days after fire) was faster than reported by those authors, probably because of differences in site, season and/or fire characteristics; moreover, the erosion of $\mathrm{NH} /-\mathrm{N}$ enriched sediments in our plots (Gomez-Rey et al., in press) could have also contributed to this tendency. No fire effect on soil $\mathrm{NO}^{\wedge}-\mathrm{N}$ concentration and a steady decreased was observed after the fire (done in autumn), contrasting with the results of Couto-Vazquez and Gonzalez-Prieto (2006) who found a peak of $\mathrm{NO}^{\wedge}-\mathrm{N}$ at $\mathrm{t}=90 \mathrm{~d}$ after an experimental fire in mid-summer, a difference likely related to the season when the soil was burned. As the emergency stabilisation treatments had no measurable effects on top-soil $\mathrm{NH} /-\mathrm{N}$ and $\mathrm{NO}^{\wedge}-\mathrm{N}$ contents, it must be 
(a)

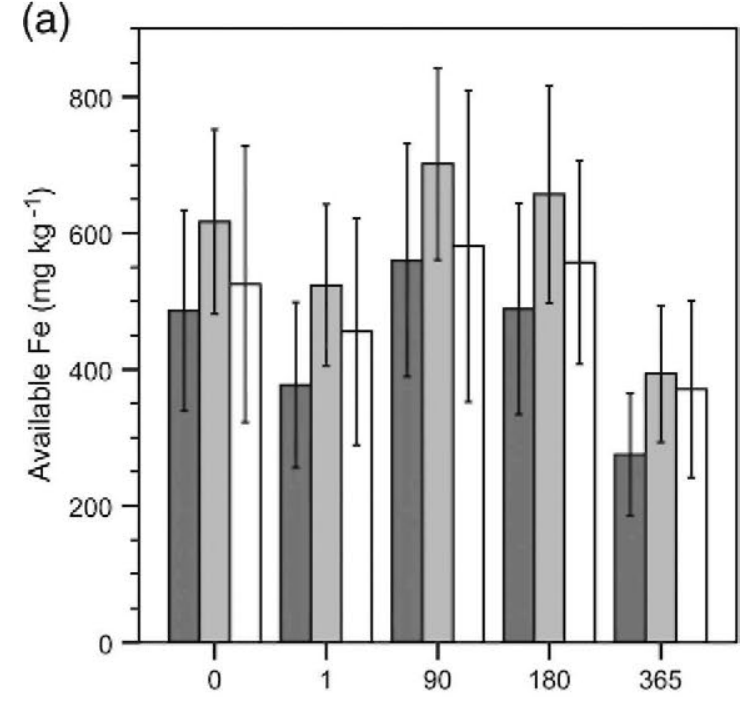

(c)

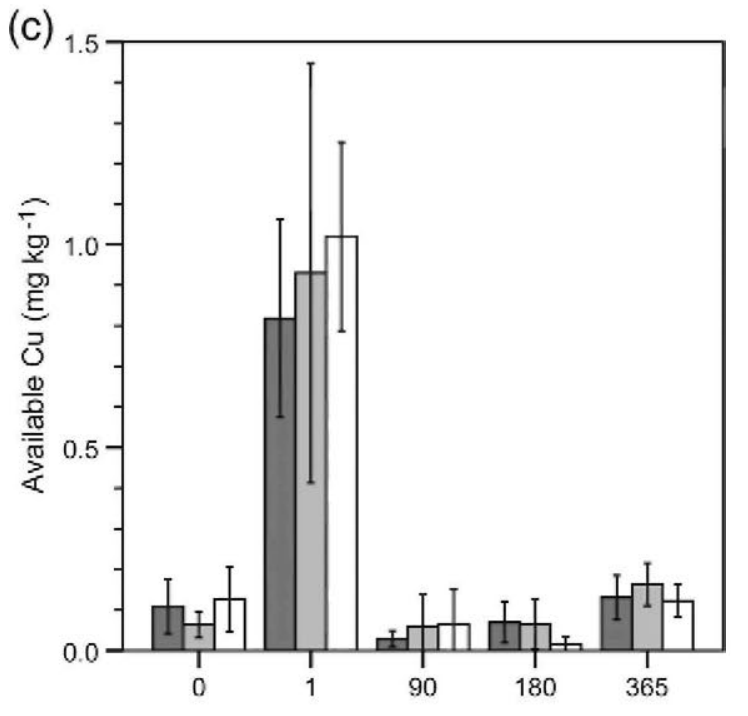

(e)

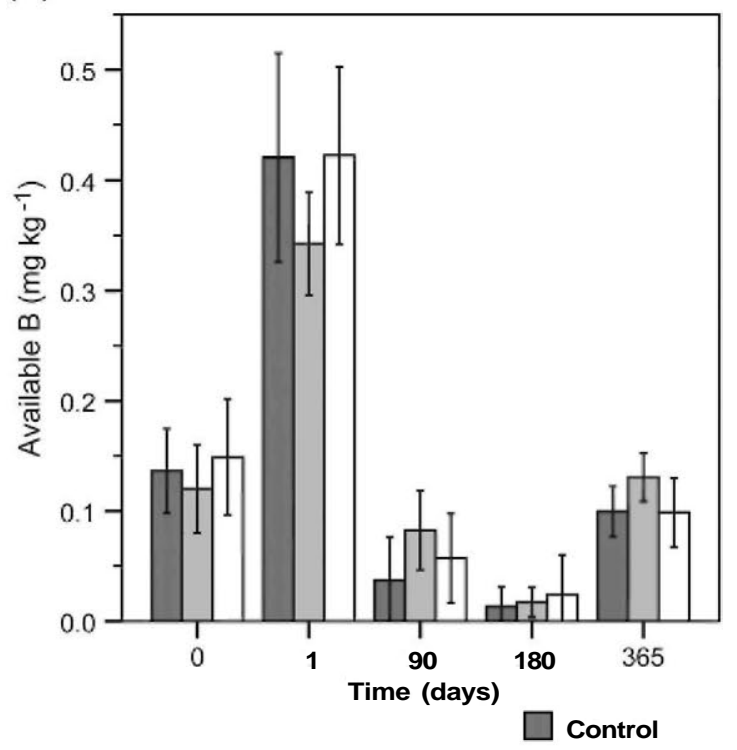

(b)

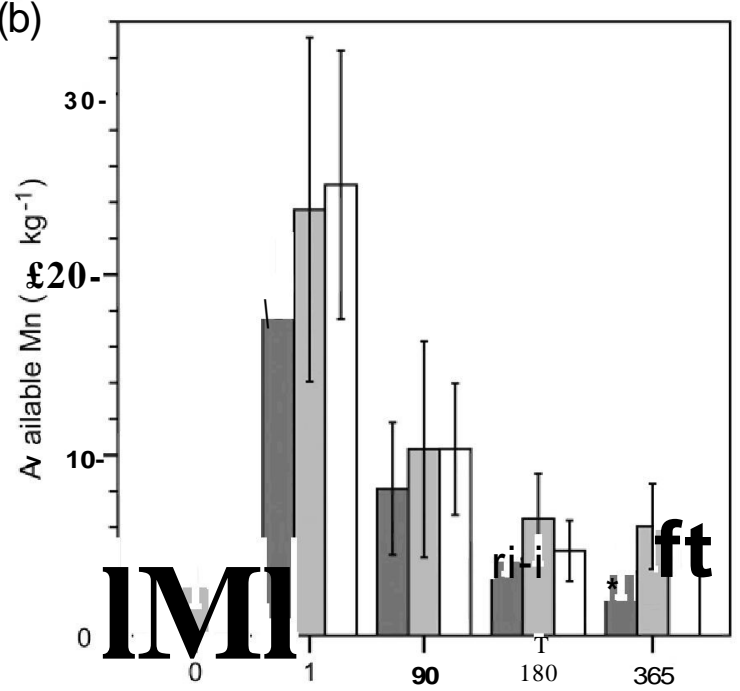

(d)

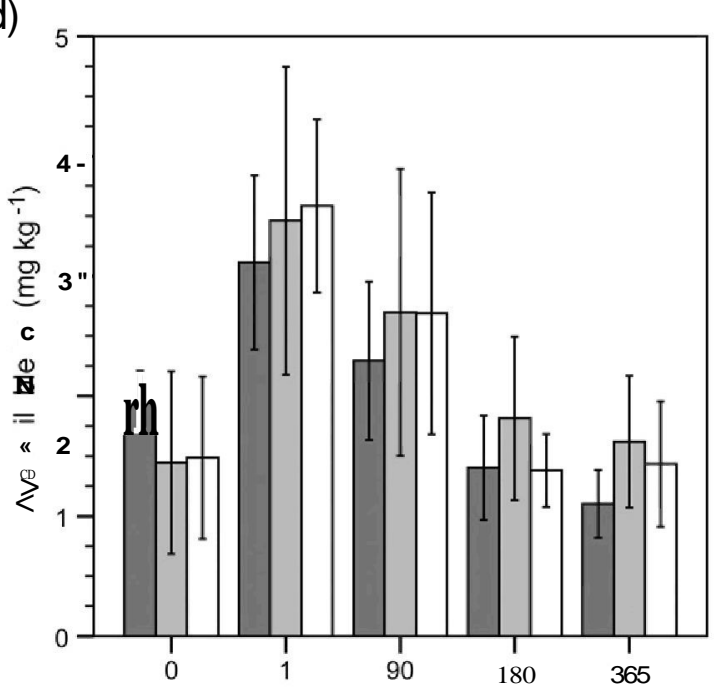

(f)

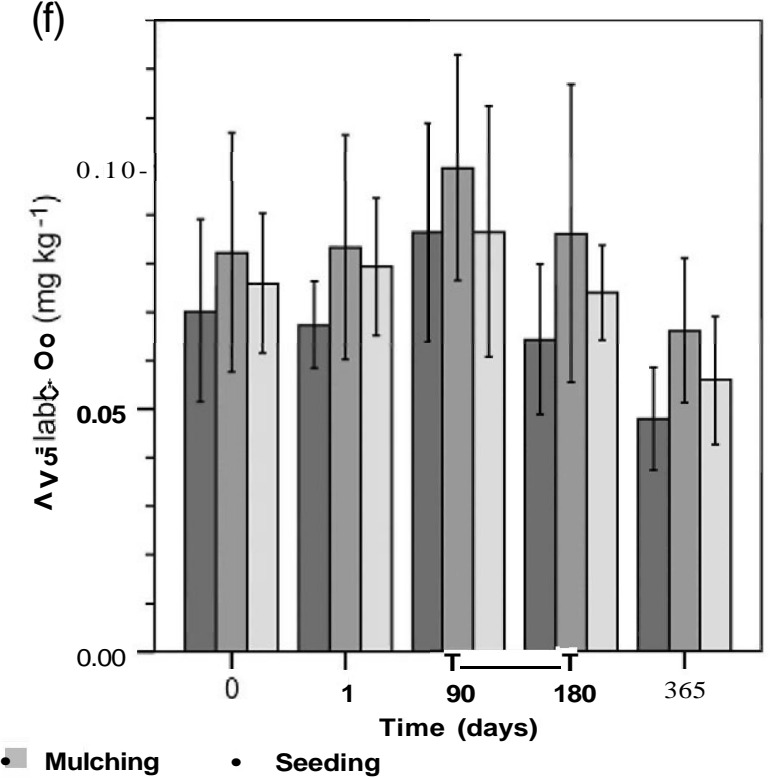

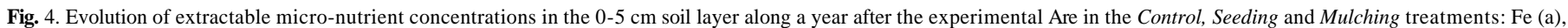
$\mathrm{Mn}$ (b), $\mathrm{Cu}$ (c), Zn (d), B (e) and Co (f). For each sampling date, no significant differences between treatments were found. 
concluded that neither Mulching nor Seeding affects the net ammonification and nitrification processes.

Although the ANOVA did not show a clear temporal trend for the SOM content, probably because of $\mathrm{C}$ richness of these soils, the regression analysis revealed a small but significant decrease with the time after fire (17\% of variance explained; $\mathrm{p}<0.01$; data not shown). This result agrees with the fact that the sediments eroded from these plots were mainly constituted by charred plant and litter material (Gomez-Rey et al., in press). In the same way, de Koff et al. (2006) found that $\mathrm{C}$ concentration in the eroded sediments increased after a prescribed fire of low severity due to the C-rich ashes, while Couto-Vazquez and Gonzalez-Prieto (2006) reported that the SOM depletion they observed in burned soil may be a medium-term consequence of the fire-triggered erosion processes on the burned plot surface. The variations on soil ${ }^{13} \mathrm{C}$ natural abundance during the study are explained by the deposition of ${ }^{13} \mathrm{C}$-depleted ashes compared with the unburned topsoil (around - 1\%o in these plots, (Gomez-Rey et al., in press); $-0.8 \%$ in charred litter, Alexis et al., 2010), pre-fire levels being recovered with the progressive erosion of ash-enriched sediments (Gomez-Rey et al., in press).

Despite Mulching had an apparent effect on soil extractable $\mathrm{Al}$, this result should be interpreted cautiously because pre-fire values of extractable Al in Mulching plots were slightly (but not significantly) lower than in other treatments.

The concentration of available basic cations increased significantly after the experimental fire, as usually reported for burned soils (Carballas, 1997; Certini, 2005; Couto-Vazquez and González-Prieto, 2006; Trabaud, 1983) due to the accumulation of ashes rich in oxides and carbonates of basic ions (Carballas, 1997; Chandler et al., 1983; Kutiel et al., 1990). The long lasting effect of fire on soil concentrations of available divalent cations (more than a year) contrasted with the much shorter period for the monovalent cations (less than six months), a difference explained by the greater solubility and propensity to leaching of the latter (Duchaufour, 1987; Khanna et al., 1994). In fact, several studies have demonstrated that the accelerated solute losses resulting from fire mainly occurred during the first months after fire (Lasanta and Cerda; 2005; Soto et al., 1995). Like for $6^{15} \mathrm{~N}$, a small but significant effect of the emergency stabilisation treatments on basic cations availability was found, the higher values observed in Seeding and, especially, in Mulching being surely related with the lower nutrient losses by erosion in those plots reported by (Gomez-Rey et al., in press).

The significant post-fire increment in available $\mathrm{P}$ compared with the unburned soils may be a result of the strong mineralizing effect of fire on organic P (Cade-Menun et al., 2000; Saa et al., 1994), while its decrease during the whole study period was surely due to: a) P-enriched sediment losses found in these plots by Gómez-Rey et al. (in press), as well as in other burned areas (Andreu et al., 1996; Saa et al., 1994); and b) orthophosphate chemisorption of Al, Fe, and Mn oxides (see Certini, 2005). The lack of effects of Mulching and Seeding on soil extractable P showed that these soil stabilisation treatments did not have a measurable influence on post-fire $\mathrm{P}$ availability.

Even thought the relatively high extractable Fe content in the ashes (Gómez-Rey et al., submitted for publication), there were no significant changes on soil Fe availability during the first half of the study, mainly as a result of the scarce solubility of this element in ashes (Khanna et al., 1994). The decline of Fe availability one year after the experimental fire, usually reported in burned soils (Close et al., 2011; Garcia-Marco and González-Prieto, 2008; Pivello et al., 2010; Ponder et al., 2009), might be associated with Fe losses with the eroded sediments (Gomez-Rey et al., submitted for publication). This depletion, also reported by Pivello et al. (2010) and Close et al. (2011), suggests that recurrent fires could led to a significant reduction of soil available $\mathrm{Fe}$, which constitutes a fertility problem in soils with low levels of plant available Fe (Garcia-Marco and Gonzalez-Prieto,
2008). The significant effect of Mulching on soil Fe availability showed by the ANOVA, should be treated with caution since the same trend among plots was already observed before the experimental fire.

The higher $\mathrm{Mn}$ availability in burned than in unburned soils agreed with results previously reported after wild (Gonzalez Parra et al., 1996) and prescribed fires (Close et al., 2011; Garcia-Marco and González-Prieto, 2008). The initial increase may be a consequence of the burned vegetation ash contribution, which contained substantial quantities of this element (Demeyer et al., 2001; Gomez-Rey et al., submitted for publication), and the physiochemical breakdown of Mn complexed with organic matter (Gonzalez Parra et al., 1996). Fire effect on available Mn lasted until the end of the study, contrasting with the lack of difference reported by Garcia-Marco and Gonzalez-Prieto (2008) and Ponder et al. (2009) one year after prescribed fires, probably due to differences in fire intensity and amount and chemical composition of ashes.

In accordance with the enhancement on $\mathrm{Zn}$ availability reported for burned soils (Close et al., 2011; Garcia-Marco and González-Prieto, 2008; StankovJovanovic et al., 2011), we found higher available $\mathrm{Zn}$ during the first 90 days after the experimental fire. This increase is consistent with the release of $\mathrm{Zn}$ by ashes from burned vegetation (Demeyer et al., 2001; Gomez-Rey et al., submitted for publication), although fire-induced changes in the soil constituents might have also contribute to this increment. The fact that most part of the variance of $\mathrm{Zn}$ concentration was explained by a simple linear regression model with days after fire (or with its logarithmic transformation), indicates that this element could be quickly leached (Zhan et al., 1996) or lost in eroded sediments (Gomez-Rey et al., submitted for publication).

The initial increase on available $\mathrm{Cu}$ was a tendency also observed by other authors (Close et al., 2011; Stankov Jovanovic et al., 2011) whereas no short-term fire effects have also been reported (Garcia-Marco and González-Prieto, 2008). The strong decline of soil available $\mathrm{Cu}$ content (linear with logarithm of days) suggested fast losses of this element from the burned soil, probably associated to complexed organic compounds or to fine particles eroded from the soil (Chirenje et al., 2002; Quinton and Catt, 2007), and agreed with the evolution of $\mathrm{Cu}$ content in sediments from the same plots (Gomez-Rey et al., submitted for publication).The evolution of soil available $\mathrm{Cu}$ content after fire could be also explained by solute losses, which increased during the first rain events following fire (see Smith etal., 2011).

Boron availability in our burned soils was higher than in the unburned ones, agreeing with the higher levels of extractable B reported for burned forest soils (Ponder et al., 2009), and for wood ash amended soils (Ferreiro et al., 2011; Merino et al., 2006). This transient increase might be explained by the high concentrations of B on ashes as soluble salts and oxides (Eary et al., 1990), which are easily dissolved (Khanna et al., 1994).

The lack of a clear tendency of soil available Co during the whole studied period agrees with the results obtained by Garcia-Marco and González-Prieto (2008) after a prescribed fire and Aref et al. (2011) after forest fires. The slightly lower available Co contents found one year after the experimental fire suggested a potential reduction in its availability after recurrent fires. As observed for $\mathrm{Fe}$, the significant increase obtained for Mulching should be cautiously interpreted.

\section{Conclusions}

During the first year after the fire, no clear temporal trend could be identified for total soil $\mathrm{C}$ and $\mathrm{N}$ content, however data suggest that the experimental fire promoted $\mathrm{NH}^{\wedge}-\mathrm{N}$ and $\mathrm{NOJ}-\mathrm{N}$ outputs, as well as the erosion of ${ }^{13} \mathrm{C}$ - and ${ }^{15} \mathrm{~N}$-depleted sediments. The post-fire transient increase of available nutrients in the topsoil lasted three months for $\mathrm{NH}^{\wedge}-\mathrm{N}, \mathrm{P}$ and $\mathrm{Cu}$, less than six months for $\mathrm{Na}, \mathrm{K}$ and $\mathrm{Zn}$ and at least one year for $\mathrm{Mg}, \mathrm{Ca}$ and $\mathrm{Mn}$. One year after the fire 
$\mathrm{NH}^{\wedge}-\mathrm{N}$ and $\mathrm{P}$ concentrations in the burned top-soil were lower than prefire levels. Our results suggest that the evolution of soil nutrients in the post-fire period should be mainly related to soil erosion dynamics and solute losses, as well as to the permanence of the ash layer. While the results were unconclusive for extractable $\mathrm{Al}, \mathrm{Fe}$ and $\mathrm{Co}$, the little but positive effects of Mulching and Seeding on $\mathrm{N}, \mathrm{K}, \mathrm{Mg}$ and $\mathrm{Ca}$ budgets point to a slightly beneficial influence of these emergency stabilisation treatments on burned soil quality.

\section{Acknowledgements}

We thank Jorge Benitez and M. Teresa Perez for their technical assistance in the laboratory. This research was supported by the Xunta de Galicia and the Spanish Ministry of Education and Science through projects numbers 08MRU002400PR and AGL2008-02823. The participation of S. Garcia-Marco and M.X. Gómez-Rey was supported by post-doctoral CS1C-13P contracts, while that of A. Couto-Vázquez was supported by a pre-doctoral CS1C-13P contract. The isotopic ratio mass spectrometer was partly financed by the European Regional Development Fund (EU).

\section{References}

Alexis, M.A, Rumpel, C, Knicker, H., Leifeld, J., Rasse, D., Pechot, N., Bardoux, G. Mariotti, A, 2010. Thermal alteration of organic matter during a shrubland Are: A field study. Organic Geochemistry 41 (7), 690-697.

Andreu, V., Rubio, J.L, Forteza, J., Cerni, R, 1996. PostAre effects on soil properties and nutrient losses. International Journal of Wildland Fire 6 (2), 53-58.

Aranibar, J.N., Macko, S.A., Anderson, I.C., Potgieter, AL.F., Sowry, R, Shugart, H.H. 2003. Nutrient cycling responses to Are frequency in the Kruger National Park (South Africa) as indicated by stable isotope analysis. Isotopes in Environmenta and Health Studies 39 (2), 141-158.

Aref, I.M., El Atta, H.A, Al Ghamde, ARM., 2011. Effect of forest fires on tree diversity and some soil properties. International Journal of Agriculture and Biology 13 (5) $659-664$

Living with wildfires: what science can tell us. In: Birot, Y. (Ed.), EFI Discussion Paper. European Forest Institute, Finland.

Bodi, M.B., Mataix-Solera, J., Doerr, S.H., Cerdà, A, 2011. The wettability of ash from burned vegetation and its relationship to Mediterranean plant species type, burn severity and total organic carbon content. Geoderma 160, 599-607.

Bodi, M.B., Doerr, S.H., Cerdà, A., Mataix-Solera, J., 2012. Hydrological effects of a layer of vegetation ash on underlying wettable and water repellent soil. Geoderma 191, $14-23$.

Brye, K.R., Norman, J.M., Gower, S.T., 2002. The fate of nutrients following three- and six-year burn intervals in a tallgrass prairie restoration in Wisconsin. The American Midland Naturalist 148 (1), 28-42.

Cade-Menun, BJ., Berch, S.M., Preston, CM., Lavkulich, L.M., 2000. Phosphorus forms and related soil chemistry of Podzolic soils on northern Vancouver Island. II. The effects of clear-cutting and burning. Canadian Journal of Forest Research 30 (11), 1726-1741

Caldararo, N., 2002. Human ecological intervention and the role of forest fires in human ecology. The Science of the Total Environment 292 (3), 141-165.

Carballas, T, 1997. Effects of fires on soil quality. Biochemical aspects. In: Balabanis, P Eftichidis, G., Fantech, R (Eds.), Forest Fire Risk and Management European Commission, Brussels, Belgium, pp. 249-261.

Cerdà, A, 1998. Postfire dynamics of erosional processes under mediterranean climatic conditions. Zeitschrift für Geomorphologie 42 (3), 373-398.

Cerdà, A, Doerr, S.H., 2008. The effect of ash and needle cover on surface runoff and erosion in the immediate post-Are period. Catena 74, 256-263.

Cerdà, A, Lasanta, T, 2005. Long-term erosional responses after Are in the Central Spanish Pyrenees - 1. Water and sediment yield. Catena 60 (1), 59-80.

Certini, G., 2005. Effects of Are on properties of forest soils: a review. Oecologia 143 (1) $1-10$

Chandler, C, Cheney, P., Thomas, P., Trabaud, L, Williams, D., 1983. Fire in forestry. Forest Are behavior and effects, vol. I. Wiley, New York.

Chirenje, T, Rivera, C, Ma, L.Q., 2002. Leachability of $\mathrm{Cu}$ and $\mathrm{Ni}$ in wood ash-amended soil as impacted by humic and fulvic acid. Geoderma 108 (1-2), 31-47.

Close, D, Davidson, N., Swanborough, P, Corkrey, R, 2011. Does low-intensity surface Are increase water- and nutrient-availability to overstorey Eucalyptus gomphocephalal Plant and Soil 349 (1), 203-214.

Cook G.D., 2001. Effects of frequent Ares and grazing on stable nitrogen isotope ratios of vegetation in northern Australia. Austral Ecology 26, 630-636.

Couto-Vázquez, A, González-Prieto, S.J., 2006. Short- and medium-term effects of three Are Aghting chemicals on the properties of a burnt soil. The Science of the Total Environment 371 (1-3), 353-361.

de Koff, J.P., Graham, RC, Hubbert, K.R, Wohlgemuth, P.M., 2006. PreAre and postAre erosion of soil nutrients within a chaparral watershed. Soil Science 171 (12) 915-928.
Debano, L.F., Conrad, C.E., 1978. The effect of Are on nutrients in a chaparral ecosystem. Ecology 59 (3), 489-497.

DeBano, L.F., Neary, D., Ffolliott, P.F., 1998. Fires Effects on Ecosystems. John Wiley and Sons, New York, USA.

Demeyer, A, Voundi Nkana, J.C., Verloo, M.G., 2001. Characteristics of wood ash and inAuence on soil properties and nutrient uptake: an overview. Bioresource Technology 77 (3), 287-295.

Diaz-Fierros, F., Benito Rueda, E., Perez Moreira, R., 1987. Evaluation of the U.S.LE. for the prediction of erosion in burnt forest areas in Galici (NW Spain). Catena 14, 189-199.

Diaz-Raviña, M., Martin, A, Barreiro, A, Lombao, A, Iglesias, L, Diaz-Fierros, F., Carballas, T, 2012. Mulching and seeding treatments for post-Are soil stabilisation in NW Spain: short-term effects and effectiveness. Geoderma 191,31-39.

Duchaufour, P., 1987. Manual de Edafologia. Masson, Barcelona

Eary, L.E., Rai, D., Mattigod, S.V., Ainsworth, C.C., 1990. Geochemical factors controlling the mobilization of inorganic constituents from fossil fuel combustion residues: II. Review of the minor elements. Journal of Environmental Quality 19 (2), 202-214.

Fernandez, C, Vega, J.A., Jimenez, E., Fonturbel, T, 2011. Effectiveness of three post-Are treatments at reducing soil erosion in Galicia (NW Spain). International Journal of Wildland Fire 20 (1), 104-114.

Ferreiro, A, Merino, A, Diaz, N., Piñeiro, J., 2011. Improving the effectiveness of wood-ash fertilization in mixed mountain pastures. Grass \& Forage Science 66 (3), 337-350.

Fisher, RF., Binldey, D., 2000. Ecology and Management of Forest Soils, 3rd ed. John Wiley, New York

Fontúrbel, M.T., Barreiro, A, Vega, J.A., Martin, A, Jiménez, E., Carballas, T, Fernảndez, C, Diaz-Raviña, M., 2012. Effects of an experimental Are and post-Are stabilization treatments on soil microbial communities. Geoderma 191, 51-60.

Garcia-Marco, S., González-Prieto, S., 2008. Short- and medium-term effects of Are and Are-Aghting chemicals on soil micronutrient availability. The Science of the Total Environment 407 (1), 297-303.

Gómez-Rey, M.X., Couto-Vázquez, A., Garcia-Marco, S., Vega, J.A., González-Prieto, S.., in press. Reduction of nutrient losses with eroded sediments by post-Are soil stabilization techniques. Int J. Wildland Fire. http://dx.doi.org/10.1071/WF12079.

Gómez-Rey, MX, Garcia-Marco, S., Fernández, C, Couto-Vâzquez, A., González-Prieto, SJ., submitted for publication. Effectiveness of post-Are soil stabilization techniques for reducing trace element losses by erosion. Int. J. Wildland Fire.

Gonzalez Parra, J., Cala Rivero, V, Iglesias Lopez, T, 1996. Forms of Mn in soils affected by a forest Are. The Science of the Total Environment 181 (3), 231-236.

Groen, AH., Woods, S.W., 2008. Effectiveness of aerial seeding and straw mulch for reducing post-wildAre erosion, north-western Montana, USA International Journal of Wildland Fire 17 (5), 559-571.

Högberg, P., Johannisson, C, Högberg, M., Högbom, L, Näsholm, T, Hällgren, J.E., 1995. Measurements of abundances of ${ }^{5} \mathrm{~N}$ and ${ }^{13} \mathrm{C}$ as tools in retrospective studies of $\mathrm{N}$ balances and water stress in forests: a discussion of preliminary results. Plant and Soil 168-169, 125-133.

Kaal, J., Carrion Marco, Y, Asouti, E., Martin Seijo, M., Martinez Cortizas, A., Costa Casais, M., Criado Boado, F., 2011. Long-term deforestation in NW Spain: linking the Holocene Are history to vegetation change and human activities. Quaternary Science Reviews 30 (1-2), 161-175

Khan, S.A, Mulvaney, RL, Mulvaney, C.S., 1997. Accelerated diffusion methods for inorganic-nitrogen analysis of soil extracts and water. Soil Science Society of America Journal 61, 936-942.

Khanna, P.K., Raison, R.J., Falkiner, R.A, 1994. Chemical properties of ash derived from eucalyptus litter and its effects on forest soils. Forest Ecology and Management 66 (1-3), 107-125.

Kutiel, P., Naveh, Z., Kutiel, H., 1990. The effects of a wildAre on soil nutrients and vegetation in an Aleppo pine forest on Mount Carmel, Israel. In: Goldammer, J.G., Jenkins, M.J. (Eds.), Fire in Ecosystem Dynamics, Mediterranean and Northern Perspectives. SPB Academic Publishing, The Hague, pp. 85-94.

Lasanta, A., Cerdà, A., 2005. Long-term erosional responses after Are in the Central Spanish Pyrenees: 2. Solute release. Catena 60, 80-101.

Merino, A, Otero, V, Omil, B, Lastra, B, Piñeiro, V, Gallego, P.P., 2006. Application of wood ash compared with ferrigation for improving the nutritional status and fruit production of kiwi vines. Journal of Plant Nutrition and Soil Science 169 (1), 127-133.

Ministerio de Agricultura y Medio Ambiente, 2012. http://www.magrama.gob.es/es/ biodiversidad/temas/defensa-contra-incendios-forestales/estadisticas-de-incendiosforestales/ (accessed 2012-06-15).

Pivello, V.R., Oliveras, I., Miranda, H.S., Haridasan, M., Sato, M.N., Meirelles, S.T., 2010. Effect of Ares on soil nutrient availability in an open savanna in Central Brazil. Plant and Soil 337 (1), 111-123.

Ponder, F., Tadros, M., Loewenstein, E.F., 2009. Microbial properties and litter and soil nutrients after two prescribed Ares in developing savannas in an upland Missouri Ozark Forest Forest Ecology and Management 257 (2), 755-763.

Prieto-Fernandez, A., ViUar, M.C., Carballas, M., Carballas, T, 1993. Short-term effects of a wildAre on the nitrogen status and its mineralization kinetics in an Atlantic forest soil. Soil Biology and Biochemistry 25 (12), 1657-1664.

Quinton, J.N., Cart, J.A., 2007. Enrichment of heavy metals in sediment resulting from soil erosion on agricultural Aelds. Environmental Science \& Technology 41 (10), 3495-3500.

Robichaud, PR, 2009. Post-Are stabilization and rehabilitation. In: Cerdâ, A, Robichaud, P.R. (Eds.), Fire Effects on Soils and Restoration Strategies. Land Reconstruction and Management Science Publishers, EnAeld, NH, USA PP- 299-320.

Robichaud, P.R, Brown, R.E., 1999. What happened after the smoke cleared: onsite erosion rates after a wildAre in Eastern Oregon. Wildland Hydrology, Proceedings.

Russell, J.D., Fraser, AR., Watson, J.R, Parsons, J.W., 1974. Thermal decomposition of protein in soil organic matter. Geoderma 11, 63-66. 
Saa, A., Trasar-Cepeda, M.C., Soto, B., Gil-Sotres, F., Diaz-Fierros, F., 1994. Forms of phosphorus in sediments eroded from burnt soils. Journal of Environmental Quality 23 (4), 739-746.

Saito, L, Miller, W.W., Johnson, D.W., Quails, R.G., Provencher, L, Carroll, E., Szameitat, P., 2007. Fire effects on stable isotopes in a Sierran forested watershed. Journal of Environmental Quality 36 (1), 91-100.

Serrasolsas, I., Khanna, P.K., 1995. Changes in heated and autoclaved forest soils of S.E. Australia. II. Phosphorus and phosphatase activity. Biogeochemistry 29 (1), 25-41.

Simard, D.G., Fyles, J.W., Pare, D., Nguyen, T., 2001. Impacts of clearcut harvesting and wildfire on soil nutrient status in the Quebec boreal forest Canadian Journal of Soil Science 81 (2), 229-237.

Smith, H.G., Sheridan, G.J., Lane, P.N.J., Nyman, P., Haydon, S., 2011. Wildfire effects on water quality in forest catchments: a review with implications for water supply Journal of Hydrology 396 (1-2), 170-192.

Soto, B., Basanta, R, Perez, R, Diaz-Fierros, F., 1995. An experimental-study of the influence of traditional slash-and-burn practices on soil-erosion. Catena 24 (1), $13-23$.

Stankov Jovanovic, V.P., Ilic, M.D., Markovic, M.S., Mitic, V.D., Nikolic Mandic, S.D., Stojanovic, G.S., 2011. Wild Are impact on copper, zinc, lead and cadmium distribution in soil and relation with abundance in selected plants of Lamiaceae family from Vidlic Mountain (Serbia). Chemosphere 84 (11), 1584-1591.
Stoof, C.R, Wesseling, J.G., Ritsema, C.J., 2010. Effects of Are and ash on soil water retention. Geoderma 159, 276-285

Trabaud, L, 1983. The effects of different Are regimes on soil nutrients levels in Quercus coccifera garrigue. In: Kruger, T.J, Mitchel, D.T., Harvis, T.U.M. (Eds.), Mediterranean type ecosystems. The Role of Nutrients. Ecological Studies, Vol. 43. Springer-Verlag, Berlin, pp. 233-243

Turner, M.G, Smithwick E.AH, Tinker, D.B, Romme, W.H, 2009. Variation in foliar nitrogen and aboveground net primary production in young postAre lodgepole pine. Canadian Journal of Forest Research 39,1024-1035.

Úbeda, X, Outeiro, LR, Sala, M, 2006. Vegetation regrowth after a differential intensity forest Are in a Mediterranean environment, northeast Spain. Land Degradation and Development 17 (4), 429-440.

Vega, J.A, Fernandez, C, Fonturbel, T, 2005. Throughfall, runoff and soil erosion after prescribed burning in gorse shrubland in Galicia (NW Spain). Land Degradation and Development 16 (1), 37-51.

Wagenbrenner, J.W, MacDonald, LR, Rough, D, 2006. Effectiveness of three post-Are rehabilitation treatments in the Colorado Front Range. Hydrological Processes 20 (14), 2989-3006.

Woods, S.W., Balfour, V, 2008. The effect of ash on runoff and erosion after a forest wildAre, Montana, U.S.A. International Journal of Wildland Fire 17, 535-548.

Zhan, G., Erich, M.S, Ohno, T, 1996. Release of trace elements from wood ash by nitric acid. Water, Air, and Soil Pollution 88 (3), 297-311. 